\title{
AQUATIC AND SEMIAQUATIC HETEROPTERA (NEPOMORPHA) FROM THE STREI RIVER BASIN
}

\author{
Daniela ILIE * and Horea OLOSUTEAN ** \\ * "Lucian Blaga” University of Sibiu, Faculty of Sciences, Department of Environmental Sciences and \\ Physics, Dr. Ion Rațiu Street 5-7, RO-550012, Sibiu, Romania, iliedf@yahoo.com \\ ** "Lucian Blaga" University of Sibiu, Faculty of Sciences, Applied Ecology Research Center, Dr. Ion \\ Rațiu Street 5-7, RO-550012, Sibiu, Romania, mesaje.facultate@yahoo.com
}

KEYWORDS: aquatic true bugs, semiaquatic true bugs, habitats, Romania.

\section{ABSTRACT}

During a field campaign in the Strei River basin in August 2014, seven suitable habitats for aquatic and semi-aquatic true bugs were identified from the confluence of the Strei River with the Bărbat River down to the confluence with the Mureș River. Forty-eight individuals belonging to 15 species and nine families of aquatic and semi-aquatic true bugs were sampled. We mention two species considered rare in Romanian fauna: Hebrus montanus and Microvelia pygmaea. The statistic-mathematical analysis showed the similarity of the true bugs' communities from habitats with similar conditions, as well as the relation of each species with particular habitat conditions, emphasizing the fact that Gerris lacustris is present in the majority of the investigated habitats, while the rest of the species are conditioned mostly by the ratio between the areas with open water and those covered by aquatic vegetation.

RESUMÉ: Les hétéroptères aquatiques et semi-aquatiques du bassin de la rivière Strei.

On cadre d'une campagne de terrain effectuée dans le bassin de la rivière Strei en août 2014, ont été identifiés sept habitats favorables aux hétéroptères aquatiques et semi-aquatiques dans la zone de confluence des rivières Strei et Bărbat, jusqu'à le jet de la dernière dans la rivière Mureş. On a collecté 48 exemplaires appartenant à 15 espèces d'hétéroptères aquatiques et semi-aquatiques, encadrées en neuf familles. Il faut mentionner l'existence de deux espèces, considérées rares, sur le territoire du pays: Hebrus montanus et Microvelia pygmaea. L'analyse statistique - mathématique effectuée, a mis en évidence la similitude des communautés d'hétéroptères dans des stations qui disposent des conditions similaires de vivre, aussi que la relation de chaque espèce avec les variables de biotope, en mettant en évidence le fait que Gerris lacustris occupe la majorité d'habitats de la zone, et les autres espèces sont conditionnées en principal de relation entre les zones qui disposent de végétation aquatique et les zones avec de l'eau libre.

REZUMAT: Heteropterele acvatice și semiacvatice din bazinul râului Strei.

În cadrul unei campanii de teren efectuată în bazinul râului Strei, în august 2014 au fost identificate un număr de şapte habitate favorabile heteropterelor acvatice şi semiacvatice, în sectorul de la confluenţa Streiului cu râul Bărbat şi până la vărsarea acestuia în Mureş. Au fost colectate 48 exemplare aparţinând la 15 specii de heteroptere acvatice și semiacvatice, încadrate în nouă familii. Menţionăm semnalarea a două specii considerate rare pe teritoriul ţării: Hebrus montanus şi Microvelia pygmaea. Analiza statistico-matematică efectuată a relevat similitudinea comunităților de heteroptere din stații cu condiții similare de habitat, precum și relația fiecărei specii cu variabilele de biotop, reliefându-se faptul că Gerris lacustris ocupă majoritatea habitatelor din areal, iar restul speciilor sunt condiţionate în principal de raportul dintre zonele cu vegetația acvatică și cele cu apă liberă. 


\section{INTRODUCTION}

Aquatic and semiaquatic bugs, reunited at present day as Infraorder Nepomorpha (Aukema, 2013), are a relatively small, polyphyletic group, with species usually considered as having wide ecological tolerances (Andersen, 1982; Jansson, 1986; Olusutean et al., 2009; Olosutean and Ilie, 2010a).

Aquatic and semiaquatic bugs were sampled in all types of water bodies, but seem to prefer stagnant or slow flowing waters, with a relatively constant presence of aquatic and semiaquatic vegetation (Karaouazas and Gritzalis, 2006; Nosek et al., 2007; Ilie and Olosutean, 2012).

Studies made in the mountainous regions of Romania show that high velocity of the water flow is a restrictive factor for the group (Olosutean and Ilie, 2010a; Ilie and Olosutean, 2012).

The Strei River is one of the main tributaries of the Mureş River (the longest river in Romania, except the Danube), with a length of $92 \mathrm{~km}$ and an basin surface of 1,926 $\mathrm{km}^{2}$, mostly in mountainous areas; the Strei River flows into the Mureş River in the sector called the Lower Mureş Couloir, between Alba Iulia and Lipova (Ujvari, 1972).

The study aims to provide insight about the aquatic and semiaquatic Heteroptera fauna from the Strei River valley, where no previous mentions of the group's members were made, as well as to analyse the relations between species and habitat characteristics.

\section{MATERIAL AND METHODS}

\section{Sampling design}

A single field campaign was conducted for sampling in August 2014, samples being collected with a $1,000 \mathrm{~cm}^{2}$ entomological net with two mm meshes. Forty-five minutes similar sampling session were taken for all samples, in order to provide quantitative data, all aspects of the habitats being covered (open water, shores with and without vegetation, submerged and floating vegetation areas, etc.).

The samples were preserved in 70\% ethylic alcohol. They were identified based on the works of Poisson (1957) and Jansson (1986). The taxonomy is presented according to Aukema (2013).

\section{Sampling area}

Upstream of the small village of Baru, the Strei River has a typical mountainous course, with narrow widths of the riverbed, high velocities of the water flow and with undeveloped vegetation on the banks; no suitable habitats for aquatic and semi-aquatic Heteroptera were found.

Downstream of the confluence with the Bărbat River and up to the confluence with the Mureş River, seven suitable habitats were identified (encoded S1 to S7; Fig. 1), from which the processed biological material was sampled. 


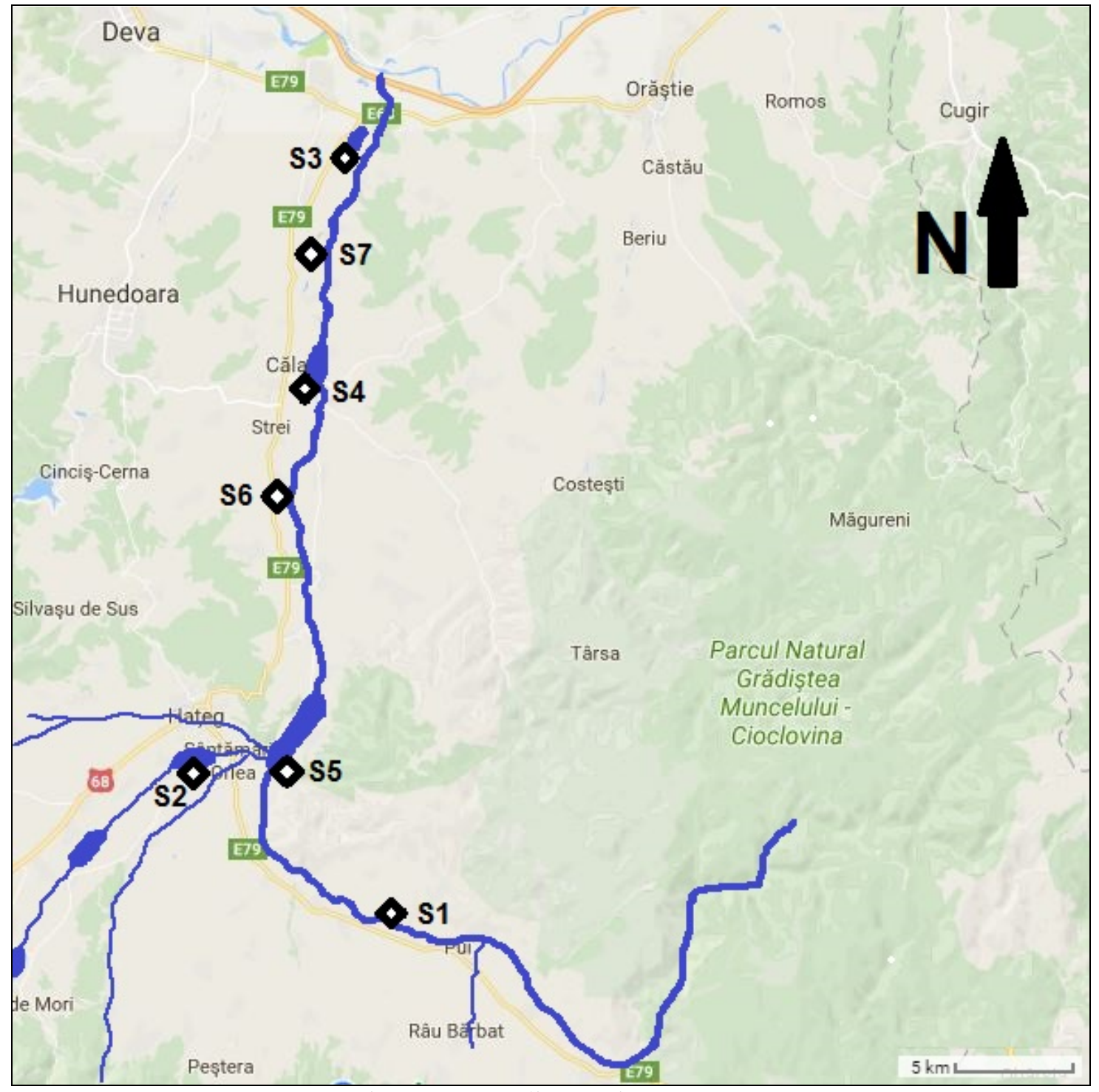

Figure 1: Sampling stations S1-S7. 


\section{S1 (4531.945’ N, 2301.983’ E, 357 m a.s.l.) (Fig. 2)}

Sampling was performed in the Strei River, in an enlarged sector of the riverbed with relatively low water flow velocity and sandy substratum. The vegetation on the banks consisted of Agrostis stolonifera, Phragmites australis, Salix sp.; aquatic vegetation was absent.

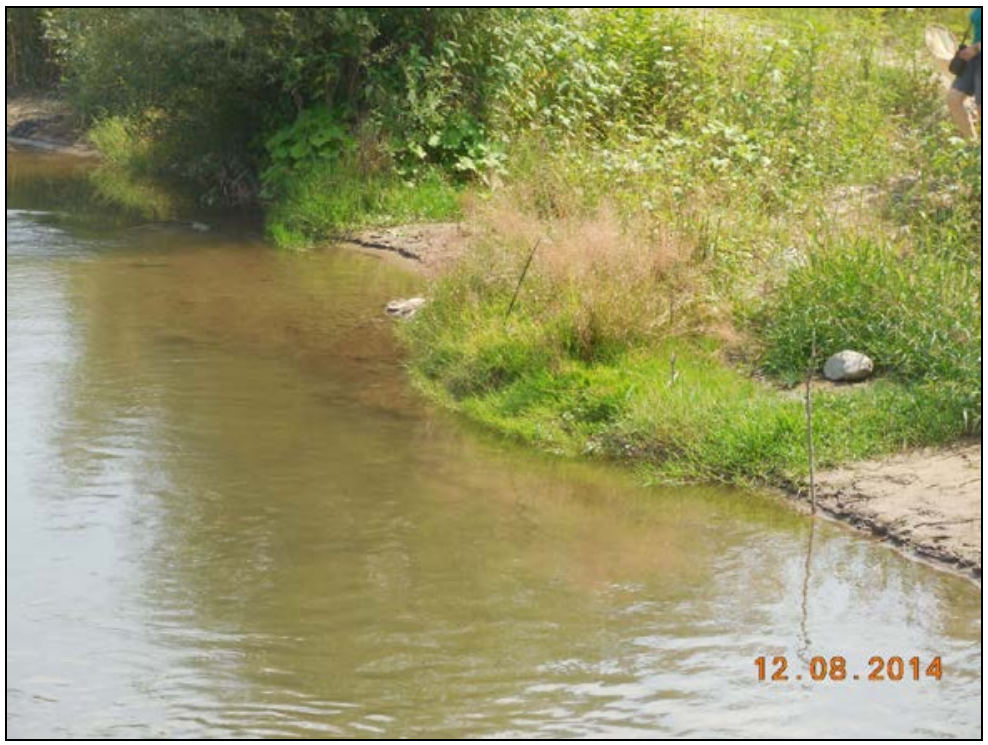

Figure 2: Sampling station S1.

\section{S2 (4535.619’ N, 2258.102’ E, 315 m a.s.l.) (Fig. 3)}

Sampling was performed in the Strei River, in an enlarged sector of the riverbed with relatively low water flow velocity and sandy substratum. The vegetation on the banks consisted of Agrostis stolonifera, Phragmites australis, Salix sp., and aquatic vegetation was absent.

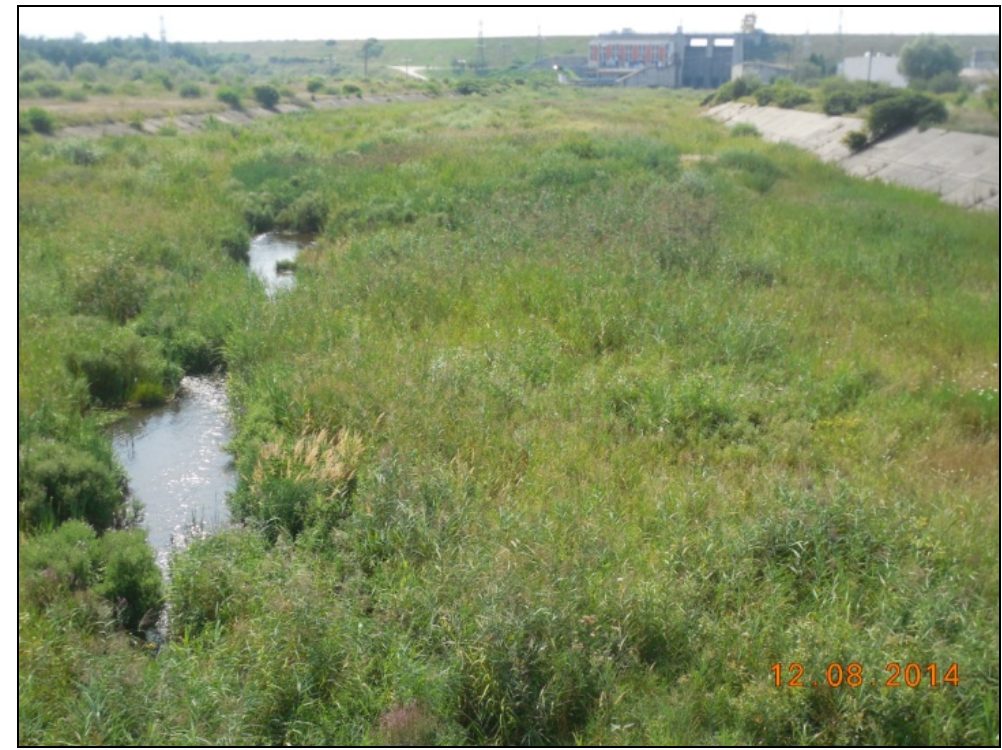

Figure 3: Sampling station S2. 
S3 (4549.745’ N, 2302.129’ E, 201 m a.s.l.) (Fig. 4)

The station consisted of a chain of small stony bottom lakes resulted from the excavations for gravel material (used for the construction of the highway), near the village of Băcia. The shores were covered by Typha latifolia, Phragmites australis, Mentha aquatica and the invasive Conyza canadensis. The floating Polygonum amphibium covered an important part of the station, as well as the vegetal association Ceratophyletum.

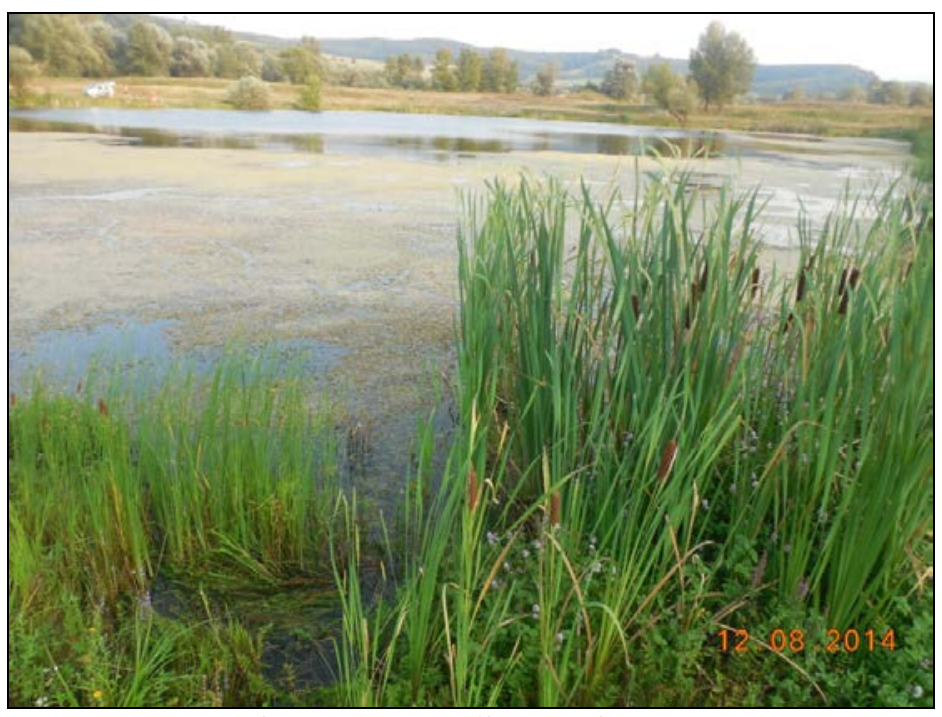

Figure 4: Sampling station S3.

S4 (4543.998' N, 2300.843’ E, altitude 243 m) (Fig. 5)

The sampling station is located on the Strei River, upstream a dam built during the communist period to provide water to industrial activities. Currently, the water flows uninterrupted, but the riverbed is widened, deep and strongly embanked. The sampled area was covered with Potamogeton crispus.

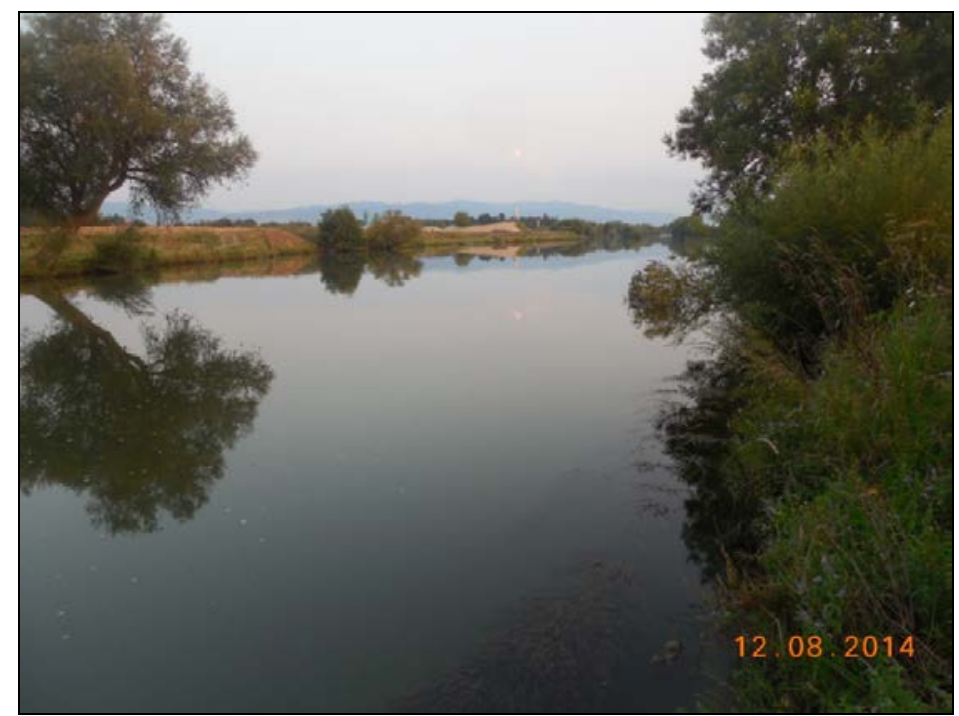

Figure 4: Sampling station S5. 


\section{S5 (4535.639’ N, 229.589’ E, 303 m a.s.l.) (Fig. 6)}

The station is located in the upstream side of lake Covragiu, with deep waters and no aquatic vegetation. A belt of reed and bulrush covers the lake shores and a large quantity of plastic bottles floats in the area.

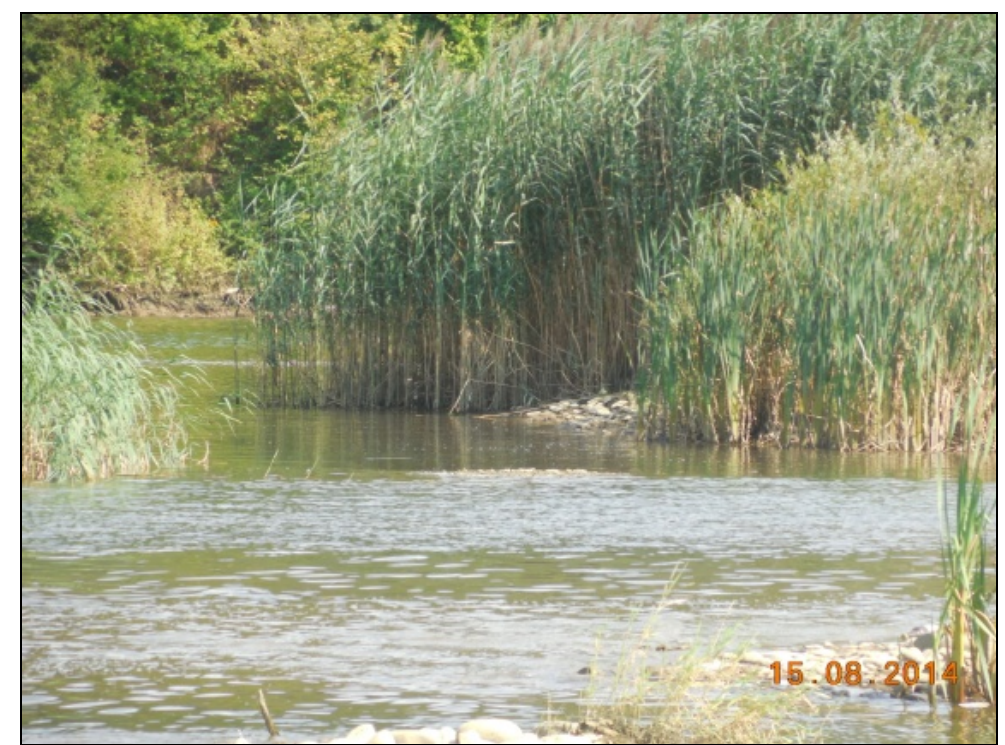

Figure 6: Sampling station S5.

S6 (4541.607’ N, 22 $59.942^{\prime}$ E, 259 m a.s.l.) (Fig. 7)

The sampling station was located in a river meander, near the Ruși Village, with stony substrate covered by a muddy residue and a Salicetum with bulrush and Calamagrosits association on the shores. The sector is presenting very high amplitudes of the water flow caused by the microhydro plant built upstream and is affected by working made for straightening the Strei River near Ruşi Village.

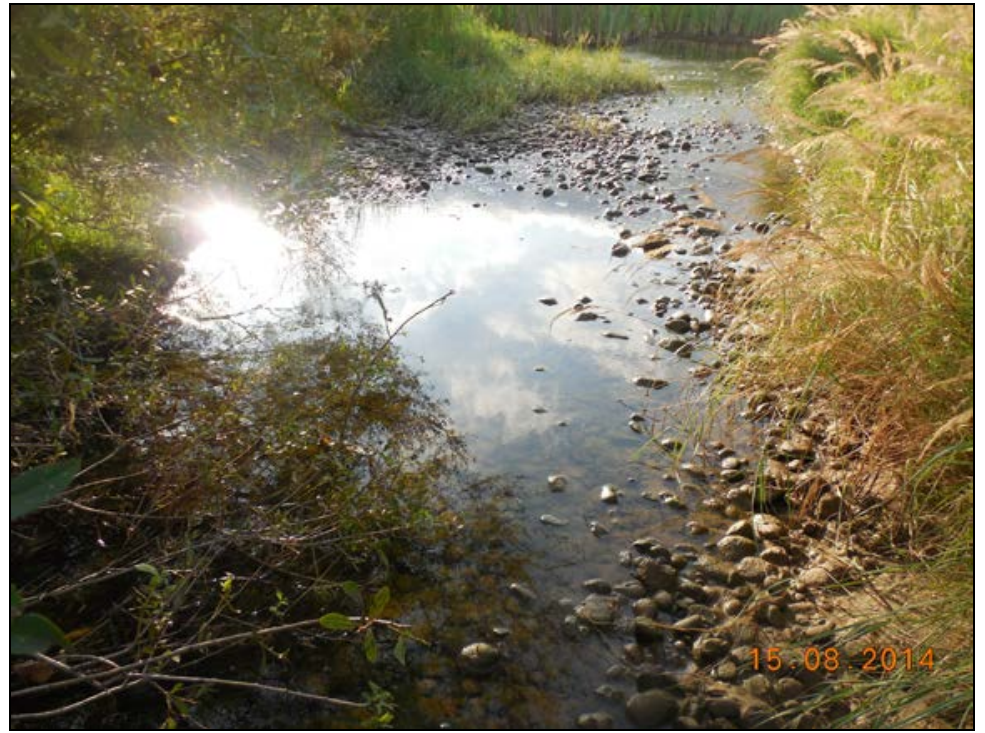

Figure 6: Sampling station S7. 
S7 (4548.143' N, 2300.651' E, 213 m a.s.l.) (Fig. 8)

The sampling station was located in the Moara Channel, with muddy substrate and very low water velocity. Emergent vegetation was abundant (Peplis portula, Lythrum salicaria, Epilobium hirsutum, Typha latifolia, Mentha longifolia, Agrostis stolonifera), as well as the floating Potamogeton nodosus, reducing the amount of open water.

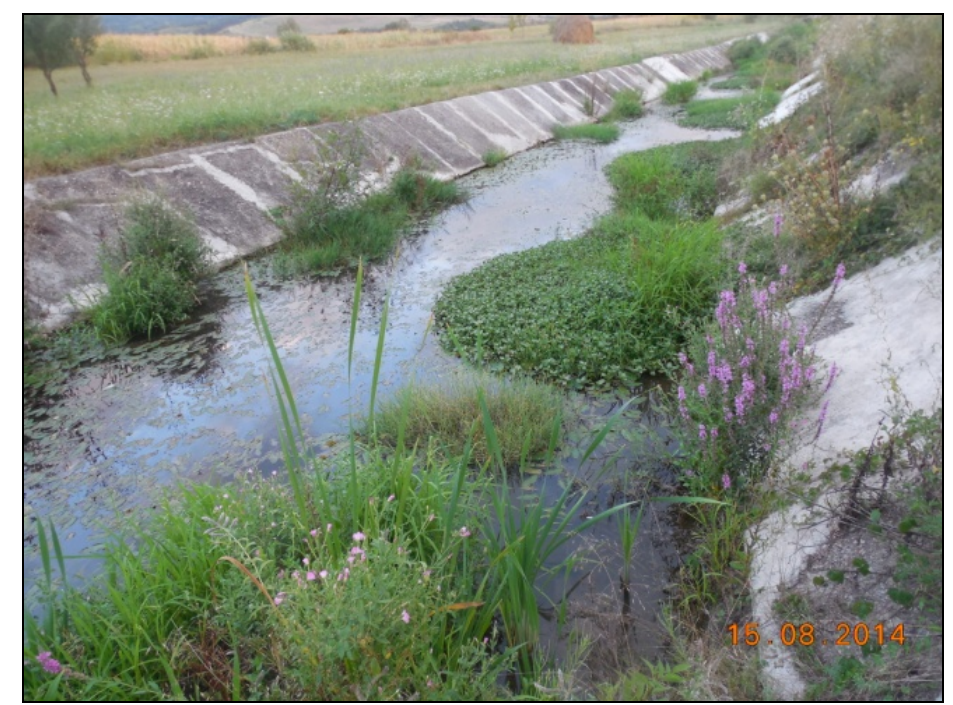

Figure 7: Sampling station S8.

\section{Statistical evaluation}

Relative abundance data (AR) was calculated for each station, and this information was used in the following analyses.

Hierarchical clustering (HC) (Lance and Williams, 1966) was used in order to assess the similarity between the investigated communities.

Canonical Correspondence Analysis (CCA) (ter Braak, 1986) was applied to point out the specific habitat preferences of each of the sampled species relating the chosen habitat characteristics to community composition (medium water depth, surface of the sampling station, percentages of coverage with aquatic vegetation and open water, respectively). Data standardization was performed on the environmental data by transforming the values in percentages of the highest value. Down-weighting of rare species was also performed. CANOCO 4.5 (ter Braak and Smilauer, 1998) was used for generating CCA results.

\section{RESULTS AND DISCUSSION}

Fifteen aquatic and semiaquatic Heteroptera species were sampled in the seven investigated habitats (Tab. 1), belonging to nine families, of which four were aquatic true bugs (Corixidae, Naucoridae, Nepidae, Notonectidae) and five were semiaquatic true bugs (Gerridae, Hebridae, Veliidae, Hydrometridae, Mesoveliidae).

Of the identified species, Hebrus (Hebrus) montanus Kolenati 1857 and Microvelia (Picaultia) pygmaea (Dufour 1833) are considered rare, with very few recordings in Romania (Ilie, 2009). 
Table 1: List and number of individuals of the species from the investigated habitats.

\begin{tabular}{|c|c|c|c|c|c|c|c|c|c|}
\hline No. & Taxa & S1 & S2 & S3 & S4 & S5 & S6 & S7 & Total \\
\hline & \multicolumn{9}{|l|}{ Infraorder Nepomorpha Popov, 1968} \\
\hline & \multicolumn{9}{|l|}{ Family Corixidae Leach, 1815} \\
\hline 1. & $\begin{array}{l}\text { Sigara (Pseudovermicorixa) nigrolineata } \\
\text { nigrolineata (Fieber, 1848) }\end{array}$ & & 1 & & & & & 2 & 3 \\
\hline \multirow[t]{2}{*}{2.} & $\begin{array}{l}\text { Sigara (Sigara) striata } \\
\text { (Linnaeus, 1758) }\end{array}$ & & & & & & 1 & & 1 \\
\hline & \multicolumn{9}{|l|}{ Family Naucoridae Leach, 1815} \\
\hline \multirow[t]{2}{*}{3.} & $\begin{array}{l}\text { Ilyocoris cimicoides cimicoides } \\
\text { (Linnaeus, 1758) }\end{array}$ & & & 2 & & & & & 2 \\
\hline & \multicolumn{9}{|l|}{ Family Nepidae Latreille, 1802} \\
\hline 4. & Nepa cinerea Linnaeus, 1758 & 1 & & & & & & 2 & 3 \\
\hline \multirow[t]{2}{*}{5.} & $\begin{array}{l}\text { Ranatra (Ranatra) linearis } \\
\text { (Linnaeus, 1758) }\end{array}$ & & & 1 & & & & & 1 \\
\hline & \multicolumn{9}{|l|}{ Family Notonectidae Latreille, 1802} \\
\hline \multirow[t]{3}{*}{6.} & $\begin{array}{l}\text { Notonecta (Notonecta) glauca glauca } \\
\text { Linnaeus, } 1758\end{array}$ & & & & & & 1 & 1 & 2 \\
\hline & \multicolumn{9}{|l|}{ Infraorder Gerromopha Popov, 1971} \\
\hline & \multicolumn{9}{|l|}{ Family Gerridae Leach, 1815} \\
\hline 7. & $\begin{array}{l}\text { Aquarius (Aquarius) paludum } \\
\text { (Fabricius, 1794) }\end{array}$ & 1 & & & 1 & 2 & & & 4 \\
\hline 8. & $\begin{array}{l}\text { Gerris (Gerris) argentatus } \\
\text { Schummel, } 1832\end{array}$ & & & 1 & & & & 2 & 3 \\
\hline \multirow[t]{2}{*}{9.} & $\begin{array}{l}\text { Gerris (Gerris) lacustris } \\
\text { (Linnaeus, 1758) }\end{array}$ & 3 & 6 & & 1 & & 2 & 1 & 13 \\
\hline & \multicolumn{9}{|l|}{ Family Hebridae Amyot and Serville, 1843} \\
\hline \multirow[t]{2}{*}{10.} & $\begin{array}{l}\text { Hebrus (Hebrus) montanus } \\
\text { Kolenati, } 1857\end{array}$ & & & 1 & & & & & 1 \\
\hline & \multicolumn{9}{|l|}{ Family Veliidae Brullé, 1836} \\
\hline 11. & $\begin{array}{l}\text { Microvelia (Microvelia) reticulata } \\
\text { (Burmeister, 1835) }\end{array}$ & & & 4 & & & & & 4 \\
\hline \multirow[t]{2}{*}{12.} & $\begin{array}{l}\text { Microvelia pygmaea } \\
\text { (Dufour, 1833) }\end{array}$ & & 4 & & & & & & 4 \\
\hline & \multicolumn{9}{|l|}{ Family Hydrometridae Billberg, 1820} \\
\hline \multirow[t]{2}{*}{13.} & $\begin{array}{l}\text { Hydrometra stagnorum } \\
\text { (Linnaeus, 1758) }\end{array}$ & 1 & & & 1 & & & 1 & 3 \\
\hline & \multicolumn{9}{|l|}{ Family Mesoveliidae Douglas and Scott, 1867} \\
\hline 14. & $\begin{array}{l}\text { Mesovelia furcata } \\
\text { Mulsant and Rey, } 1852\end{array}$ & & & 3 & & & & & 3 \\
\hline 15. & $\begin{array}{l}\text { Mesovelia vittigera } \\
\text { Horváth, } 1895\end{array}$ & & & 1 & & & & & 1 \\
\hline & Number of species & 4 & 3 & 7 & 3 & 1 & 3 & 6 & - \\
\hline & Number of individuals & 6 & 11 & 13 & 3 & 2 & 4 & 9 & 48 \\
\hline
\end{tabular}


Hierarchical clustering (Fig. 9) identified closer relations between the following groups of stations: S1 and S4, both slow flowing areas of Strei River, with a small number of species each represented by one individual; S6 and S2, both located downstream from microhydro plants, with a larger number of species than the previous group, but with a much homogeneous community composition, with Gerris lacustris as the dominant species; S3 and S7, located in areas with almost stagnant water, with well-developed vegetation, where the highest biodiversity was recorded; and S5, a habitat with intense anthropic impact, where only one species was sampled.

The CCA ordination (Fig. 10) showed that all the environmental variables are strongly correlated with the first axis, with depth, station area and open water opposed to the percentage of aquatic vegetation (depth: $\mathrm{r}=-0.802$; area: $\mathrm{r}=-0.800$; open water: $\mathrm{r}=-0.781$; aquatic vegetation: $r=0.796$ ). However, they are presenting a consistent correlation with the second axis, with depth and open water opposed to station area and to the percentage of aquatic vegetation (depth: $\mathrm{r}=-0.460$; open water: $\mathrm{r}=-0.524$; area: $\mathrm{r}=-0.453$; aquatic vegetation: $r=0.497$ ). The first two axes of the CCA (eigenvalues $\lambda_{1}=0.721, \lambda_{2}=0.431$ ) are explaining $78 \%$ of the total variation.

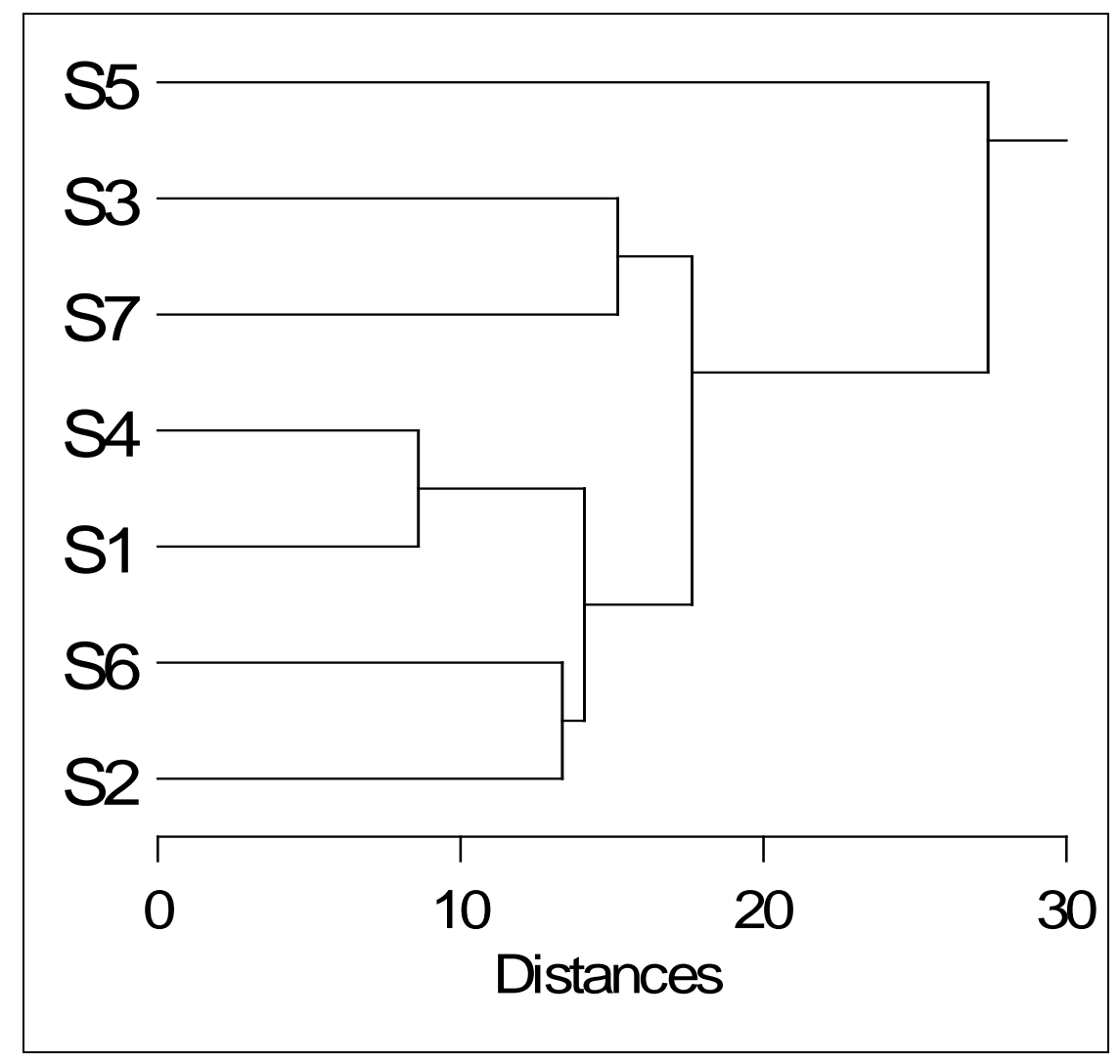

Figure 9: Similarity of the investigated communities (AR\% data, Euclidean distances, average linkage). 
The particular preferences of the species sampled, G. lacustris, highly eurivalent species for the Romanian fauna (Olosutean and Ilie, 2010a, b; Ilie and Olosutean, 2012), appears to have no apparent relation to the selected habitat variables, being found in almost all the studied habitats; N. glauca and A. paludum prefers large surfaces of open water and higher water depths; $N$. cinerea, G. argentatus, S. nigrolineata and $H$. stagnorum prefer larger habitats with well-developed aquatic vegetation; while a larger group, consisting of $H$. montanus, the two Microvelia species, $R$. linearis and $I$. cimicoides prefer smaller stations with shallow waters and well-developed vegetation, mostly in accordance with the known habitat preferences of the species in Romania (Olosutean and Ilie, 2010a, b, 2013; Ilie and Olosutean, 2012).

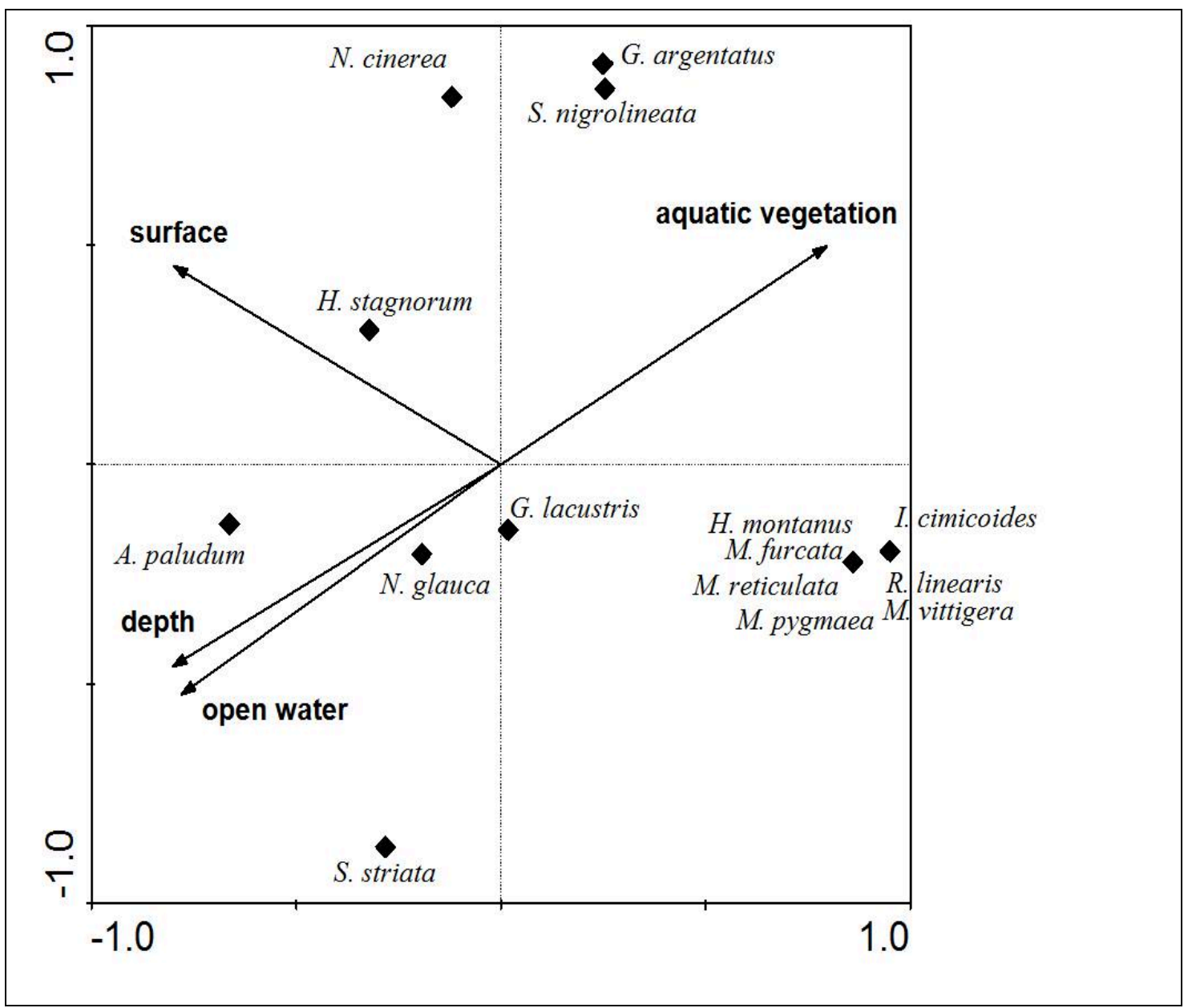

Figure 10: CCA biplot for species-habitat relations. 


\section{CONCLUSIONS}

The investigated area presents very few suitable habitats for aquatic and semi-aquatic true bugs. Although we were able to sample a relatively large number of species, the number of individuals present was extremely low, confirming the above conclusion. As known for small, anthropic affected habitats, G. lacustris is the dominant species, while the other species are mainly influenced by the ratio between the areas with open water and those covered by aquatic vegetation, in consistence with our previous studies and with the existing information from the scientific literature.

\section{ACKNOWLEDGEMENTS}

We would like to thank Mr. Drăgulescu for the identification of plant species. 


\section{REFERENCES}

1. Andersen N. M., 1982 - The Semiaquatic bugs (Gerromorpha) phylogeny, adaptations, biogeography and classification, Scandinavian Science Press Ltd., Copenhagen, 455.

2. Aukema B., 2013 - Fauna Europaea: Heteroptera, Nepomorpha, The Society for the Management of Electronic Biodiversity Data, www.faunaeur.org.

3. Ilie D. M., 2009 - Heteropterele acvatice şi semiacvatice (Heteroptera, Nepomorpha, Gerromorpha) din bazinul mijlociu al Oltului, Edit. Altip, Alba Iulia, 279. (in Romanian)

4. Ilie D. M. and Olosutean H., 2012 - Aquatic and semiaquatic Heteroptera communities from South-East Transylvanian small rivers, Travaux du Museum National d'Histoire Naturelle “Grigore Antipa”, 55, 2, 207-216.

5. Jansson A., 1986 - The Corixidae (Heteroptera) of Europe and some adjacent regions, Acta Entomologica Fennica, 47, 94.

6. Karaouazas I. and Gritzalis K. C., 2006 - Local and regional factors determining aquatic and semi-aquatic bug (Heteroptera) assemblages in rivers and streams of Greece, Hydrobiologia, 573, 199-212.

7. Lance G. N. and Williams W. T., 1966 - A general theory of classificatory sorting strategies, I, Hierarchical systems, Computer Journal, 9, 373-380.

8. Nosek J. N., Vásárheli T., Bakonyi T. and Oertel N., 2007 - Spatial pattern of waterbugs (Nepomorpha) at different scales in the Szigetköz (Hungary), Biologia, 62, 3, 345-350.

9. Olosutean H. and Ilie D. M., 2010a - Relationships between habitat characteristics and aquatic and semi aquatic Heteroptera community structure in Romanian mountainous regions: a preliminary report, Romanian Journal of Biology - Zoology, 55, 2, 139-148.

10. Olosutean H. and Ilie D. M., 2010b - Aquatic and semiaquatic Heteroptera (Nepomorpha) from the Sulina - Sfântu Gheorghe Canal (Danube Delta, Romania), Transylvanian Review of Systematical and Ecological Research, 10, 55-76.

11. Olosutean H., Ilie D. M., Axinte S. and Drăgoiu A., 2009 - Biodiversity analysis on aquatic and semiaquatic Heteroptera (Heteroptera, Nepomorpha, Gerromorpha) from two Transylvanian (Romania) lake complexes, Acta Oecologica Carpatica, II, 141-149.

12. Olosutean H., Olosutean C. and Ilie D. M., 2013 - High morphological variability of Gerris argentatus (Heteroptera, Gerridae) in the Danube Delta and probably europe's smallest gerrids', Transylvanian Review of Systematical and Ecological Research, 15, 2, 111-116.

13. Poisson R, 1957 - Hétéroptères aquatiques, Fédération Française des Sociétés de Sciences Naturelles, Paris, 263. (in French)

14. ter Braak C. J. E., 1986 - Canonical Correspondence Analysis: a new eigenvector technique for multivariate direct gradient analysis, Ecology, 67, 1167-1179.

15. ter Braak C. J. F. and Smilauer P., 1998 - CANOCO Reference Manual and User's Guide to CANOCO for Windows: Software for Canonical Community Ordination (Version 4), Microcomputer Power, Ithaca, 351.

16. Ujvari I, 1972 - Geografia apelor României, Edit. Ştiinţifică, Bucureşti, 592. (in Romanian) 